Article

\title{
Solutions for the Sustainable Management of a Cultural Landscape in Danger: Mar Menor, Spain
}

\author{
María Griñán Montealegre
}

Department of History of Art, University of Murcia, 30001 Murcia, Spain; mariagri@um.es; Tel.: +34-868-88-7770

Received: 26 October 2019; Accepted: 24 December 2019; Published: 31 December 2019

\begin{abstract}
The focus of this paper is a case study on the municipality of San Javier in Spain. The aim of the analysis was to provide a working model for the integration of the assessment and conservation of built heritage into broader projects devoted to the sustainable restoration of natural spaces undergoing evident declines in habitability. With a population of 31,905, San Javier is located on the edge of the Mar Menor, which is one of the largest permanent salt water lagoons in the Mediterranean. It forms part of the coastal region of the Autonomous Community of the Region of Murcia in the southeast of the Iberian Peninsula. San Javier is one of four municipalities that administer this unique ecosystem. However, despite being designated as a protected natural site since its 14 beaches are one of the most important national and international tourist destinations in this Autonomous Community, since 2016, it has suffered one of the worst environmental crises in its history. One of the outcomes of this situation is that the government bodies involved have begun to seek new models for the area's complete regeneration that would enable sustainable growth and also include the social and economic sectors that have, to date, played a secondary role in managing the area. In this regard, cultural heritage should play a key role. The aim of this study was to demonstrate that the region's cultural heritage, despite the complex issues involved in its management, especially for the local administrative bodies, can contribute to the creation of new models for regeneration. Besides the added value of cultural prestige provided by this area's unique cultural landscape, which is a further legacy of the region's history and artistic development, engaging with cultural heritage facilitates the revival of traditional systems that contribute to environmental improvement. Finally, this paper provides tools that enable local groups, and, above all, the residents themselves, to identify with the values of their cultural heritage.
\end{abstract}

Keywords: cultural landscape; local governance; sustainability; immovable properties; bathing houses; Mar Menor; San Javier

\section{Introduction}

The municipality of San Javier is located on the edge of the Mar Menor, which is located in Spain's Murcia region, and is one of the largest permanent salt water lagoons in Europe. It is a medium-sized town, which, according to the 2018 census [1], had a population of 31,905, although the trend toward seasonal fluctuation in its population during the summer months has become pronounced. Mar Menor forms part of a unique ecosystem, and it is listed in the Ramsar Convention for wetlands of international importance [2], in addition to being designated a protected natural space and area of special interest. The lagoon forms part of three other municipalities: San Pedro del Pinatar, Los Alcázares, and Cartagena.

The region's unique natural features are combined with other types of cultural heritage that are in diverse states of conservation across the region, and together they form a cultural landscape that is unique in Spain. However, the Mar Menor and its surrounding landscape have undergone one of the worst environmental crises in its history, which was mainly due to the agricultural overexploitation 
of the coastal region; the municipality of San Javier alone generates around 21,500 jobs in the fishing and agricultural sector. The rapid development of tourism since 1950 has alarmingly transformed the traditional urban landscape. This has been due, firstly, to the high demand for second homes [3] intended primarily for seasonal use (the municipality of San Javier generates 10,145 jobs in the service sector and almost 700 in the building sector), and secondly, the lack of planning with regard to the public and private infrastructures that drain into the lagoon.

All this occurred with the emergence of a cultural dimension of tourism in Spain from the 1980s onwards-the consolidation of democracy and the social and cultural change that led to legislative developments and the creation of a complex administration that gave local governance an unprecedented role.

Subsequently, the 2007 financial crisis launched a new economic cycle that had major repercussions for the commercial and social fabric in the region. The drastic collapse of sectors, such as the construction sector, and the reactivation of agriculture in the Mar Menor region prompted the local administration to seek new forms of tourist attraction, including cultural heritage, which, after a gradual start, has succeeded. However, the natural environment, and with it the natural and human landscape, has been the location of natural disasters clearly linked to the widely predicted impact of local malpractice and the broader effects of climate change. Since 2016, various episodes of flooding have been caused by run-off water from the region's watercourses, and these have introduced noxious substances and waste into the Mar Menor, which has had a serious effect. In parallel, the land has been overly exploited, and especially the lagoon. Unorganized urban development, excessively intensive agriculture, the construction of artificial beaches, navigable canals, heavy metal runoff, construction of marinas, and the anchoring of hundreds of ships have been slowly destroying the delicate marine meadows of the Mar Menor state since the 1980s. Since 2017, this situation has been the main cause of the progressive decrease in traditional sun and beach tourism. The greatest impact cannot yet be quantified due to the disaster caused by the recent rains in the area that triggered the low-price sales of these second homes and the loss of attraction as a tourist destination.

As a result, the different levels of administration (general, regional, and local) have begun to examine new models of integral regeneration to ensure there is sustainable growth in the region [4]. As a starting point, the premise was taken that both the importance of cultural heritage and its conservation must play an active role in the creation of new social, economic, and urban models for the Mar Menor region (see Figure 1). The main objective of this study was to demonstrate that the area's heritage and especially the real estate should be considered in the creation of these new models, which will also provide a means to revive traditional systems capable of contributing to environmental improvements. In addition, through education programs, recovering and promoting traditional trades (such as the restoration and conservation of Latin sailboats, companies specializing in sustainable maritime construction, etc.), and increased awareness, members of society could play an active role in these new social models.

When the cultural heritage of the San Javier region is addressed, its protected cultural heritage can be identified and documented and, thereby highlighting its role in the region. This study demonstrates that the repercussions of the various regional regulations on cultural heritage have not been effective, and that, in some cases, the regulations have led to the destruction of built heritage. 


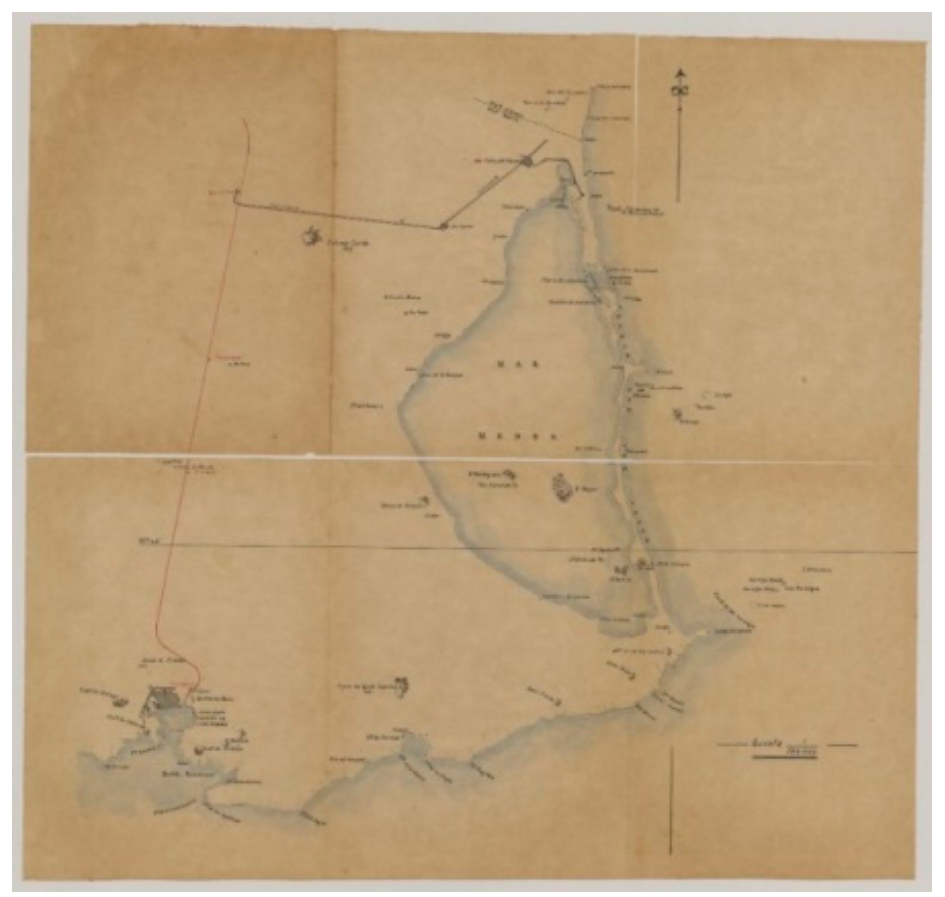

Figure 1. Mapa de la Comarca del Mar Menor by Gustavo Gilman. 1905 [5]. For more information, please entry the website at https://archivoweb.carm.es/archivoGeneral/arg.mostrar_visor3?idses=0\& id $=4001373$.

\section{Materials and Methods}

The basis of this article was the findings of the research project called Analysis of the Impact of Regeneration Strategies on the Conservation of the Cultural Heritage of Historic Industrial Areas (HAR2014-58151-R), which was funded by the Spanish government, through the state R+D+I program Addressing the Challenges Faced by Society 2014 undertaken between 2015 and 2019. A major outcome of this project and its study of a select group of municipalities was the observation that a major blind spot exists in Spanish local government policies with regard to historical artistic and cultural heritage sites. Therefore, the analysis was extended to coastal spaces, such as that studied here: a medium-sized municipality whose growth was linked to the historic evolution of a maritime space, and, despite the environmental issues that have arisen, a municipality whose historic and cultural legacy could constitute an element of cohesion for its broader region. However, to achieve this, good local government practices are required, and a further issue to be addressed is the complex bureaucratic network that affects such practices. The bureaucracy has been proven to be inefficient in the conservation and promotion of San Javier's cultural legacy, due to the heritage regulations being affected by urban planning legislation.

In various municipalities, for the preservation of cultural heritage, knowledge of the relevant cultural assets in each region must be accompanied by the understanding of their use and impact in both their specific environment and in society as a whole. Above all, the potential and advantage offered by the assets for generating individual and collective values and experiences must be considered, as well their contribution to urban sustainability. The forms of governance must be analyzed to provide information, knowledge, and tools to those responsible for both decision-making and the managers to enable improvements in the design, implementation, and evaluation of strategies and actions, in which cultural heritage could be included as a core factor. Thereby, social and cultural values and the collective dynamics of identification need to undergo a series of social changes, especially with regards to the provision of increased knowledge concerning the evolution of cultural identities and common values amidst processes of change. Finally, I aimed to demonstrate that cultural heritage 
is a key element in the construction of citizenship values, the learning of one's own history, and the identification of solutions for the challenges faced by society [6].

For this purpose, I analyzed the complex administrative network that influences wealth management and how it is based on a wide range of regulations of different legal natures. In some cases, such as the municipality of San Javier, these regulations have been the reason for the loss of some of the most significant and representative examples of cultural heritage. The balnearios [7] merit special attention as they are specific local examples of the region's architecture. Despite their importance in the image of the cultural landscape of the Mar Menor, their disappearance throughout the last decade of the 20th century was the result of a conflict between original private property owners and the application of a new Coastal Law that transformed them into public spaces (Bienes Demaniales). The general administration was not interested in these elements that were historically constructed by individual owners who not only acquired property on land but also on the coast. Finally, the local community is concerned about the area becoming a tourist destination, but are not worried about its impact on the environment and future sustainable growth.

In this study, examples of immovable properties that have been granted various categories of heritage and/or urban protection were identified and studied, and the impact of this protection with regard to the region was analyzed, which until just a few decades ago was administratively referred to as the Comarca del Mar Menor.

\section{Results}

Since 1990, many authors have assessed cultural heritage as a fundamental piece in strategic local development operations [8-11]. The association between tourism and management of cultural heritage [12-14] has been studied as an alternative to local difficulties $[15,16]$.

In Spain, cultural tourism has been extended since 2000 as an alternative to the marked dependence on sun and beach tourism, which is strongly seasonal $[8,17]$, improving the local economy by reducing seasonality and unemployment, and providing business opportunities to improve the standard of living of the population and attract European local development programs [18]. As a form of economic independence of heritage assets, cultural tourism guarantees their conservation [19], connecting heritage areas with international models that highlight the importance of cultural tourism [20-26].

Although the conceptualization and methods applied seem clear, the objectives of the International Charter on Cultural Tourism [27] indicate that its local application is basic and not yet fully effective, since the value and quality of historical and cultural assets are still measured only in terms of their ability to attract tourism [18]. Thus, except for sites with significant heritage values, museums and exhibitions have been the main devices used to attract cultural tourists. Starting a program to modernize the supply and management of museums [28-35] is a strategy that currently exists in Spain in almost all of the local heritage policies under the guidelines initiated by the Council of Europe and with the support from programs and structural funds of the European Union in its attempt to overcome regional imbalances [36,37].

In this work, the starting premise is that to preserve cultural heritage, it must be transformed into a product not only of tourist consumption, but also of cultural and identity. The disciplines of art history [38-40] and visual culture [41] are required to assist with this transition. According to Mirzoeff, the ways of seeing involve the practices of looking, with the senses of what we call the viewer, who is the one who looks or sees. The object or thing that is looked at may be an object of art or a series of things experienced by people in the present or in the past [42].

Historical, artistic, or cultural heritage [43,44] can be immovable, movable, or intangible [45-47], and is understood as a changing social creation and therefore has a relative attributed degree of value. As UNESCO indicated in its 1992 revision, during the commemoration of the 1972 Convention on the Protection of the World Cultural and Natural Heritage, the representation of European and North American cultural goods, strong predominance of religious buildings (mostly Christianity), and preponderance of historic cities and civilizations had disappeared, to the detriment of living cultures. 
In reality, the list only included a few countries, not all of humanity [45,48]. Also, the complexity of the local management of Spanish cultural heritage that is mainly due to an interdependence of diverse public and private sectors, which, in some cases, has led to the loss of a significant part of its cultural goods [49-52]. Both tangible and intangible cultural heritage aspects need to be used as an element of identity cohesion of the community, so that cultural heritage is valued as an effective tool that contributes to the sustainable development of the territory $[53,54]$. Through cultural goods, the different ways of life, customs, and beliefs are demonstrated, and therefore must be known and valued by the society that produced them. In this dialogue, society recognizes and protects not only its past but also its future.

In terms of space, certain studies Mar Menor have laid the foundation for the knowledge of its history and culture [55-59]. Conversely, research on the physical environment, its geological conformation, and its evolution and water characteristics have not recently been the object of study [60], with studies from 1978 [61-63], when natural changes and anthropogenic changes were occurring [61-68].

\section{Discussion}

A fundamental factor of the Mar Menor's historical evolution, which is crucial for understanding its current landscape, occurred over the course of the twentieth century. This was the entwined consolidation of the tourism boom and the modernization of the municipalities along the Mar Menor. The use of the Mar Menor as a place for leisure and for the therapeutic benefits of its waters by the privileged families of the kingdom of Murcia, dates back to the 17th century. The earliest extant records of the construction of leisure residences dates to this period, which were used take advantage of the water, although they were built some way from the sea due to the risk of piracy [69].

On this basis, in 1898, the village of Santiago de la Ribera was founded by the Barnuevo-Sandoval family, who owned the Torre Mínguez estate in San Javier. They transformed the ancient agrarian property into a new zone of holiday residences, equipped with the necessary maritime constructions including bathing houses (balnearios). Shortly after, something similar occurred in the other nearby villages, and especially in Los Alcázares, which, until 1990, had fallen under the jurisdiction of the municipality of San Javier. In Los Alcázares at the end of the 19th century, the Balneario de la Encarnación was built for seasonal summer use. However, in this case, the bathing house was intended for the public in order to accommodate the growing number of tourists who came from increasingly distant places, as a wide range of people enjoyed the benefits of the sea [70].

From 1960 onwards, the rate of development increased rapidly until it reached a peak in the first decade of the 21st century, not in terms of population, but in infrastructure and uncontrolled urban expansion, which considerably impacted the image of the region [71]. Until a few years ago, the popularity of Mar Menor as a unique natural space made it an increasingly important tourist destination, linked to the sea and sun, which only offered new cultural attractions in some cases, including summer events such as the Theater, Music, and Dance Festival in August and the Jazz Festival in July.

However, the elements that constituted the heritage image of the territory had been forgotten, such as the first modernist houses, navigation, and bathing houses, both by the local administration and by the community that had used them since their origin, which led to their abandonment and the loss of heritage value for neighbors. The same has not occurred with popular festivals and vernacular folklore, which have been maintained by the community $[9,46]$. This is the case for Romería de San Blas, which one of the religious traditions linked to the origins of the population in the 17th century, or Carnival. Both are celebrated in the winter months, at times of lower tourist influxes. This phenomenon indicates how the perception of heritage and its dynamic process of construction by local communities, which have already been analyzed in other parts of South America [72] or Europe [15], can guarantee the preservation of cultural heritage regardless of the support of the administration, and even beyond 
the intervention of external experts who can provide a scientific discourse on historical, artistic, and cultural content.

In this sense, this same community, in the face of conflict that involves the loss of environmental and cultural values that are fundamental to their way of life, can become an active defense agent. What role would cultural heritage have in trying to improve this situation? According to previous studies [8-10,14], the first function of cultural heritage is to legitimize a discourse based on scientific knowledge to publicize traditional uses that served to maintain the balance between humans and the environment. Simultaneously, these elements can be part of a responsible and sustainable tourism offering. The incorporation of heritage into tourism requires collaboration and coordination between the local community and tourism and cultural strategies, which should be planned according to the forms of governance [73].

In the regional regulations, the preamble of Law 4/2007 of the Cultural Heritage of the Region of Murcia defines Cultural Heritage as:

One of the main signs of identity and a testimony of the contribution made to the universal culture. The assets form an invaluable heritage and their conservation and enrichment corresponds to all the people of Murcia, and especially to the public authorities that represent them [74].

Therefore, cultural heritage is not something hieratic or ancient, but must be understood as a dynamic element, one that is part of our lives, and its value contributes to society, being incorporated into our daily lives. [75].

The history of the term cultural heritage highlights heritage as a discovery [76] in which the meaning of objects, beyond their timelessness due to their nature, is transformed according to their spectators. They can be understood by a social group as what their identity and history represents [77]. So, in our case, we propose a review through the appropriation of the community that not only recovers heritage through its rediscovery, but also feels the need to maintain it. Then, the value of equity and the contribution to the recovery of sustainable practices can be realized through external elements, especially tourism, and new technologies [72].

The core texts of international heritage doctrine underscore the concept that emerged from the UNESCO World Conference on Cultural Policies, which was held in Mexico in 1982. Despite being relatively old, this concept has not lost its contemporary relevance for defining how cultural heritage represents what we have the right to inherit from our predecessors and implies the obligation that we conserve for future generations [78]. With regard to San Javier, further insight is provided by considering the relationship between the natural environment and the landscape as a defining element of history and culture. The ICOMOS (International Council on Monuments and Sites) Burra Charter, revised and published in 1992, defends the overall conservation of cultural heritage in the places for and in which they were created, and that have been conserved in such a way that "they enrich people's lives, often providing a deep and inspirational sense of connection to the community and landscape, to the past and to lived experiences. Places of cultural significance reflect the diversity of our communities, telling us about who we are and the past that has formed us ... " [79]. In 2005, ICOMOS revised its concept of cultural sites as heritage areas on different scales, including: isolated buildings and spaces; historic cities; urban, rural, or maritime landscapes; cultural routes; and archaeological sites that gain their meaning and distinctive character from the perception of social, spiritual, historic, artistic, aesthetic, natural, and scientific values, or other factors of a cultural nature. Likewise, meaningful relationships are established between cultural heritage and its physical, visual, and spiritual surroundings. These relationships can be the result of a creative, conscious, and planned acts, spiritual belief, historical events, usage, or an organic cumulative process arising from cultural traditions over the course of time [80].

For the case study under discussion, in the Region of Murcia, concern has been growing regarding natural heritage, largely due to the impact of tourism on the local environment and the active role 
of environmental associations throughout the region. However, weaknesses continue to be detected regarding public awareness of the importance of cultural heritage and its role in local communities. Despite the publication of Law 12/2014 of 16 December 2014 on Transparency and Citizen Participation of the Region of Murcia, which provided a framework for the various forms of social participation, the Mar Menor currently lacks any non-governmental group, agency, or association whose objectives cover the partial or total protection of the cultural heritage of its territory.

Cultural goods that are protected by the local government are collected through its Urban Plan San Javier 2014 PGMO, which are the heritage assets that the local administration consider to be relevant and key elements of the municipality's identity according to the urban regulations, San Javier currently has 52 protected examples of cultural heritage (Table 1). Only 13 out of the 52 have received the maximum protection category of Cultural Interest Asset (abbreviated as BIC in Spanish) [81]. Most of these cultural assets are ethnographic in nature, especially windmills, although other examples of civil architecture are included such as the Villa Barnuevo and numerous residential summer buildings that originally included bathing houses within the Mar Menor. In Santiago de la Ribera where there is an entire catalogued urban area, the military city of Colonia Ruiz de Alda demonstrated the effects that legislation and protection have had on the heritage immovable cultural center of San Javier. Examples of religious cultural heritage are also present. These heritage sites are the most visited sites due to their artistic value and because they are where several popular shows and rites occur in the community [82]. Finally, the archaeological, terrestrial, and underwater heritage sites, located in La Manga and the Mar Menor Islands, today provide cultural value regardless of the lack of tourism prospects.

For this reason, and after analyzing the administration's proposals [83], two elements of the protected heritage were highlighted since, in a small way, they are still present in the daily lives of the local community. T first is the bathing houses because, although many have disappeared from the beaches, the regeneration expected to be conducted by the regional government includes the construction of new spas to minimize the amount of artificial beaches that have been built since 2000 to reduce negative impacts on the local environment. The second is the Vela Latina, which as a form of navigation can improve the local economy through development for tourism. 
Table 1. Cultural heritage sites protected by the San Javier PGMU (Plan General Ordenación Urbana) [84].

\begin{tabular}{lcl}
\hline BIENES & GRADO & POBLACIÓN \\
\hline ARQUITECTURA CIVIL & & \\
\hline Casa del Conde Campillo & 1 & Stgo. de La Ribera \\
Chalet Barnuevo & 1 & Stgo. de La Ribera \\
Hacienda de Roda & BIC & Roda \\
Conjunto de Edificaciones de la Isla del Barón & Incoado BIC & La Manga (San Javier) \\
Villa San Francisco Javier & 1 & Stgo. de La Ribera \\
Torre Javiera & 2 & Stgo. de La Ribera \\
Villa la Pinada & 2 & Stgo. de La Ribera \\
Casa Benimar & 2 & Stgo. de La Ribera \\
Torre García & 2 & Stgo. de La Ribera \\
Villa “El Retiro" & 2 & San Javier \\
Torre Saavedra & 3 & San Javier \\
Colonia Ruiz de Alda & 2 & Stgo. de La Ribera \\
Academia General del Aire & 3 & Stgo. de La Ribera \\
Torre Mínguez & 3 & Stgo. de La Ribera \\
Club Náutico & 1 & San Javier \\
Cuartel de la Guardia Civil & 2 & Stgo. de La Ribera \\
Casa en Paseo Colon, n ${ }^{\circ} 48$ & 3 & San Javier \\
Grupo Escolar San Javier & 3 & San Javier \\
Torre Octavio & 3 & La Manga \\
Casa en Veneziola. & 3 & La Manga \\
Casa de la Encañizada & 1 & San Javier \\
Casa Los Urreas & 3 & Stgo. de La Ribera \\
Casa en Paseo Colon, $n^{\circ}$ 46 & 3 & Stgo. de La Ribera \\
Casa en Paseo Colon, $n^{\circ} 47$ & 3 & \\
\hline
\end{tabular}


Table 1. Cont.

\begin{tabular}{|c|c|c|}
\hline BIENES & GRADO & POBLACIÓN \\
\hline ARQUITECTURA POPULAR & & Stgo. de La Ribera \\
\hline Noria de sangre de la Torre García & 3 & La Manga \\
\hline Aljibe de cúpula de la Isla Grossa & 1 & \\
\hline MOLINOS & BIC & \\
\hline Molino de Sal & & La Manga \\
\hline Molino de Sal & & La Manga \\
\hline Molino de trasegar Agua & & La Manga \\
\hline Molino Finca la Máquina & & San Javier \\
\hline Molino de Agua & & San Javier \\
\hline Molino de Harina & & San Javier \\
\hline Molino de Agua & & La Grajuela \\
\hline Molino de Agua & & La Grajuela \\
\hline Molino de Agua & & La Grajuela \\
\hline \multicolumn{3}{|l|}{ ARQUITECTURA RELIGIOSA } \\
\hline Iglesia Parroquial de San Francisco Javier & 1 & San Javier \\
\hline Iglesia Nuestra Señora de EL Rosario & 2 & El Mirador \\
\hline Ermita de San José & 3 & Pozo Aledo \\
\hline Iglesia Parroquial de Santiago Apóstol & & Stgo. de La Ribera \\
\hline \multicolumn{3}{|l|}{ BALNEARIOS } \\
\hline Balneario. Concesión 522 & Incoado BIC & Stgo. de La Ribera \\
\hline Balneario. Concesión 474 & Incoado BIC & Stgo. de La Ribera \\
\hline Balneario. Concesión 397 & $\mathrm{BIC}$ & Stgo. de La Ribera \\
\hline Balneario. Concesión 445 & $\mathrm{BIC}$ & Stgo. de La Ribera \\
\hline \multicolumn{3}{|l|}{ ÁREAS DE INTERÉS ARQUEOLÓGICO } \\
\hline Isla Perdiguera I - Exp.208/90 45 & $\mathrm{C}$ & La Manga \\
\hline Isla Perdiguera II - Exp.830/98 46 & $\mathrm{C}$ & La Manga \\
\hline La Grajuela - Exp.877/90 47 & $\mathrm{~B}, \mathrm{C}$ & La Grajuela \\
\hline La Esparteña I - Exp.828/98 48 & $\mathrm{C}$ & Isla La Perdiguera \\
\hline La Esparteña II - Exp.829/98 & $\mathrm{C}$ & Isla La Perdiguera \\
\hline
\end{tabular}

\subsection{Balnearios}

To interpret the heritage landscape as it is seen today, transformation in this region has almost always coexisted with the sea, ranging from the maritime exploitation of the lagoon to the traditional medicinal or therapeutic uses of the inhabited regions of the Mar Menor. This is demonstrated by the remains of Roman baths, as well as the construction of the Hotel de la Encarnación, which occurred centuries before that of Los Alcázares [85]. On some of the Mar Menor islands, the remains of sites intended for relaxation and pleasure can still be found, such as the residential complex of the Isla Mayor, also known as Isla del Barón, which owes its nickname to the property and buildings constructed by Julio Falcó d'Adda, Baron of Benifayó, the descendent of a Savoy family. The island served as one of the family's summer residences in the region during the 19th and 20th centuries [86].

The development of maritime leisure activities from the end of the 19th century until 1960 produced the old agricultural villages in vacation locations, including Lo Pagán, Santiago de la Ribera, Los Nietos, and Los Alcázares, which were inhabited by a population that moved to the coast for several weeks in the summer months to take baths. During that time, companies and services were installed that were permanently established near the mid-20th century.

At the same time that the leisure houses were built, in front of them, the balnearios were also built. These were wooden platforms that entered the sea so that bathers could comfortably enter the water. Each family built a corresponding spa in front of their villa. This created spatial importance between the house and the sea. Thus, balnearios served as an extension of the privacy of the residence. This 
even extended to formal details, and especially in Los Alcázares and Los Nietos, until the end of the 20th century, where some family residences exhibited decorative features, colors, and portico designs, which were the for the house and the spa and, in some cases, details were included that identified the family.

As Gutiérrez-Cortines [87] has stated, these bathing platforms played a role from the point of view of land use, since they served to alleviate overcrowding on the beaches and provided a solution to the rocks and mud on the shore. As of 1965, high apartment buildings were constructed, and once again, spas were built in front of these buildings that were 500 to $1000 \mathrm{~m}^{2}$, and fulfilled the same social function as social interaction spaces, also serving as moorings for pleasure boats and jetties for water sports. However, with the construction of artificial beaches and the increased demand for space for bathrooms, the balnearios were considered to be obsolete pieces in the maritime landscape as of 1990 .

These balnearios were not only intended for bathing or mooring boats, as is the case today, but some, practically from the outset, were also used for social gatherings in the form of literary or intellectual gatherings, dancing, and other leisurely pursuits. The construction of the yacht club in la Ribera in 1918, which was known as the Casino Marítimo de la Ribera, is an example of this trend. In 1971, this casino was transformed into the current building, the Real Club de Regattas de Santiago of la Ribera.

From the 1960s onward, the combination of the mass tourism phenomenon, new building techniques, the exhaustion of the traditional tourism model, and the development of extensive legislation under Spain's new democratic government meant that a series of legal and economic circumstances in the 1980s led to the disappearance of the majority of the bathing houses. Mar Menor underwent a form of intervention that transformed the region to fit the mold of modernity being sought at that time. The Project for the Rehabilitation of the Beaches was launched by the Coastal Commission, which depended on the Ministry for Public Works and Urban Planning [88]. Its aim was to create artificial beaches that would facilitate bathing and the enjoyment of the seaside, and this drastically affected the traditional image of the coast and led to the elimination of the majority of the maritime buildings.

In 1987, the Committee for Culture of the Region of Murcia began the process of designating the complex of the Mar Menor balnearios as a BIC to protect and conserve these fragile maritime architectural structures. However, this measure was never implemented and only a limited form of the initial project led to the conservation of some bathing houses, either due to their singular value, or their good state of conservation, or because their social or economic role permitted it. However, in the majority of the cases, this measure only managed to delay an inevitable decline, as was the case with the Lonja, the historic municipal fishmongers, and the restaurant the Pescadería de Mariche. In the latter case, despite its kitchens having conserved long-established seafood traditions of sampling the caldero de mújol (a stewed mullet dish) by the edge of the Mar Menor, the restaurant could not stave off demise following the Coastal Commission's cessation of the temporary concession of 50 to 100 years that it had been granted when it opened.

This is the aspect that has begun to work with the community of neighbors. The awareness of the planned construction being a solution for the regeneration and use of beaches through the construction of new maritime platforms is based on the tradition of the oldest construction in the area. Therefore, awareness campaigns are being conducted at the administration level through advice and meetings with experts. Conferences are being promoted within the communities with publication of informative brochures about the history and traditional uses of these popular locations [88].

What objectives have been set for these actions? At the level of local governance, the strategy of maintaining the affected and protected structures has been reported (Table 1), which would have been maintained according to traditional construction systems. On an economic level, this would entail a lowering of costs and their maintenance would require traditional crafts such as additional works of wood, network systems, and esparto. The strategy would help improve an innovative, unique offer for bathing in the sea and attract new tourism. The local community would benefit because it would lead to tourists continuing to be attracted to the area. 
The Hotel Los Arcos in La Ribera, opened in August 1960 by Adrián Viudes Guirao with its beach resort, is an example that could be recovered as an example of the contemporary policy of attracting quality national and international tourism. In 1981, after being closed for several years, Hotel Los Arcos was transformed into a hospital. In early 2011, the hospital was transferred to Pozo Aledo and the empty building, currently and provisionally, is a training center for the San Javier regattas, but is waiting for a project that to confirm its position as a historic element in Santiago de la Ribera (Figure 2).
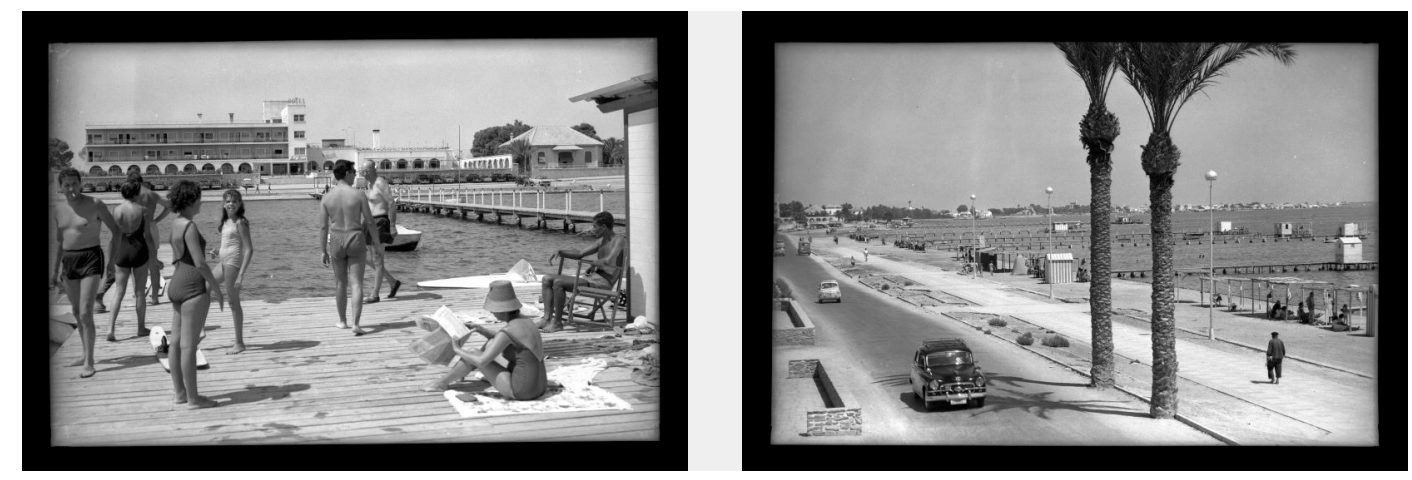

Figure 2. Bathing houses at Hotel Los Arcos and Santiago de la Ribera, part of the municipality of San Javier, 1965, Murcia [89].

\subsection{La Vela Latina}

Maritime, sports, and leisure activities are the best known aspects of identity in the region. The Latin Sail (Vela Latina) is a vessel with rigging and sails used for both professional fishing and marine sports without motor. They symbolize the knowledge and trades related to this practice. In February 2018, the Autonomous Community of the Region of Murcia (CARM) protected the Latin Candle as a BIC $[90,91]$.

According to the extensive report provided by the Higher Technical School of Naval and Oceanic Engineering of the Polytechnic University of Cartagena, "Vela Latina sailing is the result of the uses and customs that involve a technical knowledge of undoubted value in the historical knowledge of navigation". The rich cultural heritage that results from this relationship between man and the environment deserves to be taken care of and conserved, especially when many of these practices are an example of sustainability, essential even for the conservation of biological diversity [92].

Villa Barnuevo, which was the first home built in the new city of Santiago de la Ribera, is an example of modernist architecture [93], which has become a center of restoration and entertainment of this sport. Although the Villa Barnuevo was declared BIC, in recent decades, its conservation status has decreased. Work is underway to complete a transformation into a study center of this art of navigation, including programming guided tours through which visitors can be informed about the history of this navigation system. Sailing with a Latin sail was inseparable from the primitive traditional and original fishing systems of the Mar Menor: the fishing weirs. This system is also practiced in the other Spanish salty lagoons, the Albudera of Valencia [94]. Therefore, the Valencian initiatives were taken as a reference, since this navigation system has also been protected since 2016. Its existing promotional initiatives, through increasing visibility of its sports activities and competitions, provide a reference for San Javier.

\section{Conclusions}

The administrative structure in which Spanish cultural heritage is framed is structured by a network of overlapping entities that affect different territorial sectors and management levels. Thus, the state coordinates the interventions in the assets that are under its jurisdiction, which include cultural 
heritage sites located on the peninsular coast. In this case study, the state has particular influence on the public domain, both on land and at sea, as stipulated by the powers assigned to the Secretary of State for the Environment, which cover the coasts, the sea, and the continental waters. The regulations covering Spanish coastal heritage as public domain assets and their application with respect to San Javier have resulted in the loss of most of their bathing houses between 1990 and 2015. Similarly, according to the Commission created by the Ministry for Ecological Transition (MPTE), despite Mar Menor being environmentally protected as a wetland inscribed on the Ramsar list, included in the Natura 2000 Network, categorized as a Community of Importance (LIC) and a Special Protection Area for Birds (ZEPA), and a Specially Protected Area of Interest for the Mediterranean (ZEPIM), these efforts have been insufficient to preserve the affected area.

In conclusion, the effectiveness of preserving and managing their cultural heritage does not depend on the degree of protection granted, since, in most cases, the effectiveness is not supported by the actual results. However, this inefficiency has proven extensible to the natural environment and its heritage values. Therefore, a series of measures have been initiated to involve not only the city council but also the local community in the recovery processes $[9,11,15]$.

The concept of citizen participation has become a basis for protection proposals and this phenomenon could affect the case study region [95]. To achieve this, we must overcome the problem of a large percentage of the population only identifying in a limited way with cultural heritage. Above all, their perception of the past could become an element of cohesion and provide a means to distinguish San Javier from other nearby regions $[8,10]$.

In the case of San Javier, if this method has been effective for another the municipalities, it can be applied to other cities related to Mar Menor. The transformative process will affect a wider community, as the patrimonialization of their territories and common traditions, in addition to favoring the external visibility of the territory and, therefore, tourism [14,16,17], can become a fundamental basis for promoting sustainable growth based on the recovery of traditional forms of production in the lagoon.

In conclusion, the Mar Menor has a cultural heritage whose assets are unique. In accordance with the five objectives established by the UNESCO Convention of Budapest 2002 [95] for World Heritage, the community involved in this case, including the residents and the seasonal population that owns second residences in the area, must have an essential role in the discovery, valuation, and new uses of cultural heritage so that these buildings can become models of sustainable use of tourism since, through their cultural and identity potential, they provide motivation for a change in mentality about the use of the weakened natural environment. The enjoyment values of the lagoon can be increased through the use of responsible activities such as sailing sports, which eventually replace the tourism offer of the sun and the beach, and bathing houses, which contribute to lessening the impact of artificial beaches. For this, the population must be engaged in campaigns of active participation in defense of heritage, promoting associations with non-governmental organizations (NGOs) whose basic objective is heritage protection [96]. This is the aim of UNESCO through actions such as the World Heritage Volunteers Campaign 2020, and is one of the basic objectives, in accordance with the 2030 agenda, of sustainable development established by United Nations Program for Development (UNDP) since 2015, also known as the global objectives [97].

Now that we are aware of the dimension of the problem and the real situation of the natural and cultural values of the region have been analyzed, the cooperation of all the social agents involved is needed. With the basic objective of immediate action in addressing the situation and knowing that, according to UNESCO, this has led to many successful restorations [75], the support of the International Community should be requested to start the process for the inclusion of the Mar Menor as a global project for its declaration as a World Heritage Site.

Author Contributions: For research articles with several authors, a short paragraph specifying their individual contributions must be provided. The following statements should be used "conceptualization, M.G.M.; methodology, M.G.M.; formal analysis, M.G.M.; investigation, M.G.M.; resources, M.G.M.; data curation, 2019 M.G.M.; writing-M.G.M.; visualization M.G.M. All authors have read and agreed to the published version of the manuscript. 
Funding: This article presents findings of the research project Análisis del impacto de estrategias de regeneración urbana sobre la conservación del patrimonio cultural de zonas industriales históricas (Analysis of the impact of regeneration strategies on the conservation of the cultural heritage of historic industrial areas) (HAR2014-58151-R), which was funded by the Spanish government, through the State R+D+I programme 'Orientada a los Retos de la Sociedad 2014 (Addressing the Challenges Faced by Society 2014)' and undertaken between 2015 and 2019.

Conflicts of Interest: The author declares no conflict of interest.

\section{References and Notes}

1. Instituto Nacional de Estadística España. 30035 San Javier. Available online: http://www.ine.es/jaxiT3/Datos. htm?t=28831 (accessed on 12 August 2019).

2. Ramsar Convention Secretariat. An Introduction to the Ramsar Convention on Wetlands, 5th ed.; Ramsar Convention Secretariat: Gland, Switzerland, 2016; Available online: https:/www.ramsar.org/sites/default/ files/documents/library/handbook1_5ed_introductiontoconvention_e.pdf (accessed on 8 June 2019).

3. García Sánchez, A.; Artal Tur, A.; Ramos Parreño, J.M. El turismo del Mar Menor: Predominio de la segunda residencia. Cuad. Tur. 2002, 9, 33-44. Available online: https://revistas.um.es/turismo/article/view/21981 (accessed on 8 June 2019).

4. Barragán, J.M.; García Sanabria, J. Estrategia de Gestión Integrada de Zonas Costeras del Sistema Socio-Ecológico del Mar Menor y su Entorno; Consejería de Presidencia y Fomento CARM: Murcia, Spain, 2018.

5. Gustavo Gillman, B. Mapa de la Comarca del Mar Menor by Gustavo Gilman; Archivo General de la Región de Murcia (AGRM): Murcia, Spain, 1905; Gustavo Gillman Bovet, ingeniero y fotógrafo. 248.6.

6. The Manifiesto de Boadilla (Boadilla Manifiesto), February 2019, was launched by the civic groups and associations that met at the 16th Jornadas en Defensa del Patrimonio Cultural de España (Conference for the Defence of Spanish Cultural Heritage), where they declared their intention to create the Federación Nacional de Asociaciones (National Federation of Associations) which would act as an intermediary with the state administrative entities. They also advocated the urgent need to undertake conservation, dissemination, promotion and educational activities with regard to cultural heritage across all tiers of society. Manifiesto de Boadilla. Asociaciones en Defensa del Patrimonio Cultural, 2019; p. 2. Available online: https://madridciudadaniaypatrimonio.org/sites/default/files/pdf-embed-blog/manifiesto_boadilla_ asociaciones_en_defensa_del_patrimonio (accessed on 2 September 2019).

7. author's note: The translation of this term as bathing house does not do full justice to the architectural construction referred to by this Spanish term and described in this article, hence the Spanish term is used.

8. Ashworth, G.; Voodg, H. Marketing of tourism places: What are we doing? J. Int. Consum. Mark. 1994, 6, 5-19. [CrossRef]

9. Antón, S. Turismo y Gestión Municipal del Patrimonio Cultural; AECIT: Gijón, Spain, 1996.

10. Harvey, D.C. Heritage Pasts and Heritage Presents: Temporality, meaning and the scope of heritage studies. Int. J. Herit. Stud. 2001, 7, 319-338. [CrossRef]

11. Zamora Acosta, E. Sobre patrimonio y desarrollo. Aproximación al concepto de patrimonio cultural y su utilización en procesos de desarrollo territorial. Pasos 2011, 9, 101-113. [CrossRef]

12. Timothy, D.; Boyd, S. Heritage Tourism; Peqrson Education Lm.: Essex, UK, 2003.

13. McKercher, B.; Du Cros, H. Cultural Tourism: The Partnership between Tourism and Cultural Heritage Management; Rodledge-Haworth Press: New York, NY, USA, 2002.

14. Landorf, C. Managing for sustainable tourism: A review of six cultural World Heritage Sites. J. Sustain. Tour. 2009, 17, 53-70. [CrossRef]

15. Du Cros, H. A new model to assist in planning for sustainable cultural heritage tourism. Int. J. Tour. Res. 2001, 3, 165-170. [CrossRef]

16. Mydland, L.; Grahn, W. Identifying heritage values in local communities. Int. J. Herit. Stud. 2012, 18, 564-587. [CrossRef]

17. Smith, V.L. Anfitriones e Invitados. Antropología del Turismo; Endymion: Madrid, Spain, 1992.

18. Camarero, C.; Garrido, M.J. Marketing del Patrimonio Cultural; Prámide: Madrid, Spain, 2004.

19. Hernández, J.B.; Tresserras, J.J. Gestión del Patrimonio Cultural; Ariel: Barcelona, Spain, 2001.

20. Barre, J. Vendre le Tourisme Culturel. Guide Méthodologique; Institut d' Éstudes Superieurs des Arts: París, France, 1995. 
21. Carter, B.; Grimwade, G. Balancing use and preservation in cultural heritage management. Int. J. Herit. Stud. 1997, 3, 45-53. [CrossRef]

22. Kirshenblatt-Gimblett, B. Destination Culture: Tourism, Museums, and Heritage; University of California Press: Berkeley, CA, USA, 1998.

23. Bendix, R. Cultural tourism in Europe. Ann. Tour. Res. 1999, 26, 1031-1037.

24. Barre, H. Cultural Tourism And Sustainable Development. Mus. Int. 2002, 54, 126-133. [CrossRef]

25. Michael Hall, C. Geography, Marketing and the Selling of Places. J. Travel Tour. Mark. 1997, 6, 61-84. [CrossRef]

26. Dimanche, F.; Havitz, M.E. Consumer Behavior and Tourism: Review and Extension of Four Study Areas. J. Travel Tour. Mark. 1995, 3, 37-57. [CrossRef]

27. International Council On Monuments and Sites. Carta Internacional sobre Turismo Cultural La Gestión del Turismo en los sitios con Patrimonio Significativo. In Proceedings of the 12th Asamblea General ICOMOS en México, México, 17-23 October 1999.

28. Herreman, Y. Museum and Tourism: Culture and Consumption. Mus. Int. 1998, 50, 4-12. [CrossRef]

29. Lord, B.; Lord, G.D. Manual de Gestión de Museos; Ariel: Barcelona, Spain, 1998.

30. Goulding, C. The Museum Environment and the Visitor Experience. Eur. J. Mark. 2000, 34, 261-278. [CrossRef]

31. Gilmore, A.; Rentschles, R. Changes in Museum Mnagement. A Custodial or Marketing Emphasis? J. Manag. Dev. 2002, 21, 745-760. [CrossRef]

32. Chaumier, S. Des Musées en Quête d'Identité (Nouvelles Études Anthropologiques); L'Harmattan: Paris, France, 2003.

33. Silberberg, T. Cultural Tourism and Business Opportunities. For Museum Heritage Sites. Available online: https://www.lord.ca/Media/Artcl_Ted_CultTourismBusOpps.pdf (accessed on 12 December 2019).

34. Asenjo, E. (Ed.) Lazos de Luz Azul: Museos y Tecnologías 1, 2 y 3.0; UOC (Universitata Operta de Cataluya): Barcelona, Spain, 2011.

35. Moreré Molinero, N.; Perelló Oliver, S. Turismo Cultural. Patrimonio, Museos y Empleabilidad; FundaciónEOI: Madrid, Spain, 2013; Available online: https:/www.eoi.es/es/savia/publicaciones/20726/turismo-culturalpatrimonio-museos-y-empleabilidad (accessed on 9 September 2019).

36. Marchena, M.J. Turismo Urbano y Patrimonio Cultural. Una Perspectiva Europea; Junta de Andalucía: Sevilla, Spain, 1998.

37. Verdugo Santos, J. El patrimonio histórico como factor de desarrollo sostenible. Una reflexión sobre las políticas culturales de la Unión y su aplicación en Andalucía. Cuad. Econ. Cult. 2003, 1, 55-90.

38. Morales, A.J. Patrimonio Histórico-Artistico; Historia 16: Madrid, Spain, 1996.

39. Hernandez Martínez, A. ¿Qué hace una chica como tú en un lugar como este?(Algunas reflexiones acerca de la relación entre Historia del Arte y Patrimonio Cultral). Artigrama 2000, 15, 543-564.

40. Cuetos, P. El Patrimonio Cultural. Conceptos Básicos; Prensas Universitarias de Zaragoza: Zaragoza, Spain, 2011.

41. Dikovitskaya, M. Visual Culture: The Study of the Visual after the Cultural Turn; The MIT Press: Cambridge, MA, USA, 2005.

42. Mirzoeff, N. Una Introducción a la Cultura Visual; Paidos: Madrid, Spain, 2003.

43. Debray, D. Vida y Muerte de la Imagen. Historia de la Mirada en Occidente; Paidós: Barcelona, Spain, 1994.

44. Brugère, F. Le musée entre la culture populaire et le divertissement. En quelle culture défendre? Sprit 2002, 283, 46-58.

45. Martí, H.I.; Manuel, G.; Santamarina Campos, B.; Moncusí Ferré, A.; Rodrigo, M.A. La Memoria Construida. Patrimonio Cultural y Modernidad; Tirant lo Blanch: Valencia, Spain, 2005.

46. Hobsbawm, E.; Ranger, T. (Eds.) La Invención de la Tradición; Crítica: Barcelona, Spain, 2002.

47. Fernández de Paz, E. De tesoro ilustrado a recurso turístico: El cambiante significado del. PASOS Rev. Tur. Patrim. Cult. 2006, 4, 1-12.

48. Matías, A.R. Historia del Arte y Patrimonio Cultural de España; Sintesis: Madrid, Spain, 1997.

49. Blanc Altemir, A. El Patrimonio Común de la Humanidad. Hacia un Régimen Jurídico Internacional de su Gestión; Bosch: Barcelona, Spain, 1992.

50. Cebrián Abellán, A. Turismo Cultural y Desarrollo Sostenible. Análisis de Áreas Patrimoniales; EDITUM: Murcia, Spain, 2002.

51. Abad Liceras, J.M. Administraciones Locales y Patrimonio Histórico; Montecorvo: Madrid, Spain, 2003.

52. Santana, A. Turismo cultural, culturas turísticas. Horiz. Antropol. 2003, 20, 31-57. [CrossRef] 
53. Prats, L. La mercantilización del patrimonio: Entre la economía turística y las representaciones identitarias. PH Bol. Inst. Andal. Patrim. Hist. 2006, 58, 72-80. [CrossRef]

54. Crespi Vallbona, M.; Planells Costa, M. Patrimonio Cultural; Síntesis: Madrid, Spain, 2010.

55. Amador de los Ríos, R. España, sus Monumentos y Artes. Murcia y Albacete; Tip. Daniel Cortezo: Barcelona, Spain, 1889.

56. Jiménez de Gregorio, F. El Municipio de San Javier en la Historia del Mar Menor; Academia alfonso X el Sabio: Murcia, Spain, 1984.

57. Torres-Fontes, J. Repartimiento y Repoblación en el Siglo XIII; Academia Alfonso X el Sabio: Murcia, Spain, 1990.

58. Cutillas Victoria, B. Proteger y defender la Manga del Mar Menor: Estudio histórico-arqueológico de la Torre de San Miguel del Estacio y la Torre de la Encañizada. Defensive Archit. Mediterr: XV XVIII centuries. 2015, 1, 95-102. [CrossRef]

59. Victoria Moreno, D. Los Alcázares y el Mar Menor: El complejo tránsito a la Modernidad. En AAVV, Historia de los Alcázares; CARM: Murcia, Spain, 2008; Volume II, pp. 1-34.

60. Buitigieg, J. La despoblación del Mar Menor y sus causas. Bol. Pescas Dir. Gral. Pesca Minist. Mar. Inst. Esp. Oceanogr. 1927, 133, 251-286.

61. Lillo Carpio, M. Geomorfologia litoral del Mar Menor. Pap. Dep. Geogr. 1978, 8, 9-46.

62. López-Bermúdez, F.; Ramírez, L.; Martín de Agar, P. Análisis integral del medio natural en la planificación territorial: El ejemplo del Mar Menor. Murcia (VII) 1981, 18, 11-20.

63. Pérez-Ruzafa, I.M. Fitobentos de una Laguna Costera. El Mar Menor. Ph.D. Thesis, University of Murcia, Murcia, Spain, 1989.

64. Arévalo, L. El Mar Menor como sistema forzado por el Mediterráneo. Control hidráulico y agentes fuerza. Bol. Inst. Esp. Oceanogr. 1988, 5, 63-95.

65. Mas Hernández, J. El Mar Menor.: Relaciones, Diferencias y Afinidades Entre las Lagunas Costeras yel Mar Mediterráneo Adyacente. Ph.D. Thesis, Universidad Autónoma de Madrid, Madrid, Spain, 1994.

66. Romero Díaz, A. Belmonte SerratoF. Los paisajes geomorfológicos de la Región de Murcia como recurso turístico. Cuad. Tur. 2002, 9, 103-122. Available online: https://revistas.um.es/turismo/article/view/21931/ 21221 (accessed on 24 June 2019).

67. Cabezas, F. Balance Hídrico del Mar Menor. El Mar Menor. Estado Actual del Conocimiento Científico; Fundación Instituto Euromediterráneo del Agua: Murcia, Spain, 2009.

68. Baudron, P. Anthropisation d'un Système Aquifère Multicouche Méditerranéen (Campo de Cartagena, SE Espagne). Approches Hydrodynamique, Géochimique et Isotopique. Ph.D. Thesis, Université de Montpellier 2, Montpellier, France, 2014.

69. Thompson, I.A. Guerra y Decadencia. Gobierno y Administracción en la España de los Austrias. 1560-1620; Crítica: Barcelona, Spain, 1981.

70. Larrinaga, C. Patrimonio del sector turístico: Los balnearios. El caso guipuzcoano. Áreas Rev. Int. Cienc. Soc. 2010, 29, 91-100.

71. Troitiño Vinuesa, M.Á.; Troitiño Torralba, L. Patrimonio y turismo. Scr. Nova Rev. Electrón. Geogr. Cienc. Soc. 2016, 20, 527-551.

72. Dormaels, M. Identidad, comunidades y patrimonio local: Una nueva legitimidad social. Alteridades 2012, 22, 9-19.

73. Griñán Montealgre, M.; Trigueros Molina, J.C. Patrimonio y Paisaje Cultural del agua en el Valle de Ricote. E-rph 2018, 22, 5-36.

74. Ley 4/2007 de Patrimonio Cultural de la Región de Murcia. Available online: http://noticias.juridicas.com/ base_datos/CCAA/mu-14-2007.html (accessed on 6 May 2019).

75. UNESCO. “Culture: Urban Future”. The Role of Cultural Heritage for Sustainable Local Development. 2017. Available online: https://whc.unesco.org/en/events/1395 (accessed on 12 February 2019).

76. Davallon, J. Comment se fabrique le patrimoine? Sci. Hum. Hors Sér. 2002, 36, 74-77.

77. Dormaels, M. The concept behind the word. In Understanding Heritage: Perspectives in Heritage Studies; Marie-Theres, A., Roland, B., Britta, R., Eds.; Walter de Gruyter: Berlin, Germany, 2013; pp. 107-115.

78. Informe Final de la Conferencia Mundial Sobre Políticas Culturales; UNESCO: Paris, France, 1982; p. 7. Available online: https://unesdoc.unesco.org/ark:/48223/pf0000052505_spa (accessed on 8 February 2019).

79. Carta de Burra para Sitios de significación Cultural. ICOMOS Australia. 1999. Preámbulo. Available online: https://www.icomos.org/charters/burra1999_spa.pdf (accessed on 8 February 2019). 
80. Declaración Sobre la Conservación del Entorno de las Estructuras, Sitios y Áreas Patrimoniales -Xi'an (China), ICOMOS. 22 October 2005. Available online: https://www.icomos.org/images/DOCUMENTS/Charters/xiandeclaration-sp.pdf (accessed on 8 February 2019).

81. 25 Ley 16/1985, de 25 de Junio, de Patrimonio Histórico Español. Available online: https://www.boe.es/ buscar/act.php?id=BOE-A-1985-12534 (accessed on 2 May 2019).

82. Ministerio de Cultura y Deporte. Gobierno de España, Regímenes Especiales de Protección del Patrimonio Histórico, Madrid, Spain. Available online: http://www.mecd.gob.es/cultura-mecd/areas-cultura/patrimonio/ bienes-culturales-protegidos/niveles-de-proteccion/regimenes-especiales.html. (accessed on 2 May 2019).

83. Comunidad Autónoma de la Región de Murcia. Estrategia de Gestión Integrada de Zonas Costeras del Sistema Socio-Ecológico del Mar Menor y su Entorno. Available online: https://www.carm.es/web/pagina? IDCONTENIDO=106035\&IDTIPO=10\&RASTRO $=\mathrm{c} \$ \mathrm{~m} 122,70$ (accessed on 3 October 2019).

84. Ayuntameniento de San Javier. Bienes Inmuebles Protegidos Desde el Plan General Municipal de Ordenación de San Javier. In Registro General de Bienes Culturales dependiente de la Consejería de Educación y Cultura de la Región de Murcia; Ayuntameniento de San Javier: San Javier, España; Available online: http://www.pgmo. sanjavier.es/textos/02-3-1\%20Catalogo\%20de\%20Bienes\%20Protegidos-PGMO-AP\%202014.pdf (accessed on 15 May 2019).

85. VVAA. El Papel de Nuestra Historia. Los Alcázares, San Pedro del Pinatar, San Javier. Murcia; Tres Fronteras: Murcia, Spain, 2009; pp. 17-23.

86. Cegarra Beltrí, G. Arquitectura Modernista en la Región de Murcia; Mablaz: Cartagena, Colombia, 2013 ; p. 215.

87. Gutiérrez-Cortines Corral, C. La Arquitectura del Agua: Los Balneario del Mar Menor. Imafronte 1990, 19, 79-92.

88. irección General de Patrimonio Histórico. (Consejería de Cultura y Educación de la CARM). The Proyecto de Rehabilitación de las Playas (Project for the Rehabilitation of the Beaches) was launched by the Junta de Costas (Coastal Commission), which depended upon the Ministerio de Obras Públicas y Urbanismo (Ministry for Public Works and Urban Planning). Murcia, Spain. Its aim was to create artificial beaches that would facilitate bathing and the enjoyment of the seaside, and this drastically affected the traditional image of the coast and led to the elimination of the majority of the maritime buildings.

89. AGRM. ES.30030.AGRM/71. 71.12./Postales y Documentos de San Javier y La Ribera (1822-1965). Serie Costa de la Luz. Available online: https://archivoweb.carm.es/archivoGeneral/arg.muestra_detalle?idses=0\& pref_id=4343958 (accessed on 15 October 2019).

90. Decreto, n. 7/2018, de 31 de enero, del Consejo de Gobierno de la Comunidad Autónoma de la Región de Murcia, por el que se declara Bien de Interés Cultural inmaterial(BIC) la Vela Latina y los oficios y saberes relacionados con su práctica. Boletín Oficial Región de Murcia, 8 febrero. 2018, pp. 2898-2906. Available online: https://www.borm.es/services/anuncio/ano/2017/numero/1619/txt?id=755120 (accessed on 1 October 2019).

91. Ley 10/2015 para la Salvaguardia del Patrimonio Cultural Inmaterial. (BOE 126, de 27 de mayo de 2015, art.1 45289). Available online: https://www.boe.es/buscar/doc.php?id=BOE-A-2015-5794 (accessed on 2 May 2019).

92. Available online: https://www.laopiniondemurcia.es/consejo-gobierno/2018/01/31/ (accessed on 22 September 2019).

93. La Spina, V.; Serrano Hidalgo, M.C. El Modernismo en la Región de Murcia; Universidad Politécnica de Cartagena, CRAI Biblioteca: Murcia, Spain, 2017.

94. El Levante (Valencia). Available online: https://www.levante-emv.com/valencia/2018/12/02/vela-latinareivindica-bic-segundo/1803368.htm (accessed on 9 May 2019).

95. UNESCO. Textos básicos de la Convención del Patrimonio Mundial de 1972. Available online: http: //www.icomos.es/wp-content/uploads/2017/05/DIRECTRICES.pdf (accessed on 22 October 2019).

96. UNESCO. Join the World Heritage Volunteers Campaign 2020. Available online: https://whc.unesco.org/en/ news/2061 (accessed on 12 October 2019).

97. UNDP. 2030 Agenda for Sustainable Development. Available online: https://www.undp.org/content/undp/ en/home/2030-agenda-for-sustainable-development.html (accessed on 12 October 2019).

(C) 2019 by the author. Licensee MDPI, Basel, Switzerland. This article is an open access article distributed under the terms and conditions of the Creative Commons Attribution (CC BY) license (http://creativecommons.org/licenses/by/4.0/). 